\title{
UJIAN NASIONAL DAN PROBLEM SOSIAL (Sebuah Analisis Terhadap Kebijakan Pendidikan Sebagai Proses Pengembangan Kepribadian)
}

\author{
Hairiyah \\ (Dosen PAI STIA Alma Ata Yogyakarta) \\ Abstract
}

National exam or Final examination as an instrument to determine the student's achievement by the end of this year still become an interesting discussion to be discussed. This theme is great interesting because it has big implications on many components including on the students. This paper will discuss the implications of national exam to personality development of students. It will begin with the basic policy implemented UN and be continued with the implications of the implementation of related social problems of personality development students. The writer also reveals about the advantages and disadvantages of many educational components as a result of the implementation of the UN.

Keyword; National Exam, Student's personality development.

\section{A. PENDAHULUAN}

Pendidikan merupakan salah satu sektor penting dalam pembangunan di setiap Negara. Menurut undang-undang No. 20 Tahun 2004, secara umum pendidikan diartikan sebagai usaha sadar dan terencana untuk mewujudkan suasana belajar dan proses pembelajaran agar peserta didik secara aktif mengembangkan potensi dirinya untuk memiliki kekuatan spiritual keagamaan, pengendalian diri, kepribadian, kecerdasan, akhlak mulia, serta keterampilan yang diperlukan dirinya, masyarakat, bangsa dan negara. ${ }^{1}$ Prof. Dr. H. Noeng Muhadjir dalam salah satu bukunya menyebutkan bahwa pendidikan mempunyai tiga fungsi, yaitu: 1) menumbuhkan kreativitas subyek-didik; 2) memperkaya khasanah budaya manusia, memperkaya isi nilai-nilai insani dan nilai-nilai Ilahi; dan 3) menyiapkan tenaga kerja produktif. ${ }^{2}$ Untuk mencapai tujuan pendidikan yang mulia ini maka disusunlah kurikulum yang merupakan seperangkat

${ }^{1}$ DEPDIKNAS, Undang-Undang Republik Indonesia No. 20 Tabun 2003 Tentang Sistem Pendidikan Nasional, Pasal I, ayat 1.

${ }^{2}$ Noeng Muhadjir, Ilmu Pendidikan Dan Perubahan Sosial (Yogyakarta: Rake Sarasin, Edisi V, 2003), hal. 20. 
rencana dan pengaturan mengenai tujuan, isi, bahan dan metode pembelajaran. Kurikulum digunakan sebagai pedoman dalam penyelenggaraan kegiatan pembelajaran untuk mencapai tujuan pendidikan yang telah ditentukan. Untuk melihat tingkat pencapaian tujuan pendidikan, diperlukan suatu bentuk evaluasi.

Evaluasi dalam pendidikan sangatlah penting. Ia adalah salah satu komponen utama yang tidak dapat dipisahkan dari rencana prndidikan. Oleh karena itu setiap orang yang berkecimpung di dalam dunia pendidikan hendaknya mempunyai pengetahuan dan pemahaman yang baik tentang evaluasi sebagai bekal kepadanya untuk dapat melakukan kegiatan evaluasi yang baik.

Evaluasi dalam dunia pendidikan diperlukan sebagai; pertama, mengukur kemajuan, juga perkembangan anak didik setelah melakukan kegiatan belajar dalam waktu tertentu, kedua untuk menunjang penyusunan rencana yang efektif dan efisien sehingga dapat membawa organisasi kepada penggunaan sumber daya pendidikan secara efisien-ekonomis, dan ketiga untuk memperbaiki/ menyempurnakan kembali program yang ada setelah dilihat hambatan, kesulitan dan penyimpangan yang ada. ${ }^{3}$

Teknik evaluasi secara garis besar dapat dibedakan menjadi dua, pertama teknik evaluasi yang berbentuk tes, meliputi tes tertulis, tes lisan, dan tes perbuatan. Kedua teknik evaluasi yang berbentuk non tes. Dalam penggunaannya evaluasi teknik tes biasanya digunakan untuk mengukur penguasaan pengetahuan teoritis, sedang teknik non tes biasa digunakan untuk mengukur keterampilan dengan perbuatan, sikap dan pertumbuhan anak dalam psikologi anak dengan bentuk non tes, seperti observasi, skala sikap, wawancara dan lain-lain. ${ }^{4}$

Dalam Undang-Undang Sisdiknas pasal 58 ayat 1, dijelaskan bahwa evaluasi peserta didik dilakukan oleh pemerintah untuk memantau proses, kemajuan, dan perbaikan hasil belajar peserta didik secara berkesinambungan, sedangkan pasal 58 ayat 2 dijelaskan bahwa evaluasi peserta didik, satuan pendidikan, dan program pendidikan dilakukan oleh lembaga mandiri secara berkala, menyeluruh, transparan, dan sistemik untuk menilai pencapaian standar nasional pendidikan. ${ }^{5}$

${ }^{3}$ Nanang Fatah, Landasan Manajemen Pendidikan (Bandung: Remaja Rosdakarya, 1996), hal. 108

${ }^{4}$ Zaenal Arifin, Evaluasi Instruksional (Bandung: Remajarosdakarya, 1991), hal. 49

5DEPDIKNAS, Undang-Undang Republik Indonesia No. 20 Tabun 2003 Tentang Sistem Pendidikan Nasional, Pasal 58, ayat 1 dan 2. 
Mengacu dari beberapa uraian di atas secara teoritis bentuk tes secara umum dapat diterima banyak orang, tetapi berkaitan dengan tes yang dikenal dengan Ujian nasional (UN) menjadi perdebatan yang tidak pernah selesai diantara pembuat kebijakan, pelaku pendidikan, pengamat pendidikan, dan bahkan masyarakat umum yang tidak tahu betul tentang pendidikan. Pada satu sisi kebijakan tersebut hendak mengangkat mutu dan kualitas pendidikan, tetapi pada sisi lain kebijakan tersebut justru memarjinalkan sebagian potensi peserta didik. Oleh karena penulis tertarik mengangkat tema ini terkait dengan pemberdayaan lembaga pendidikan.

\section{B. PEMBAHASAN}

\section{Peraturan UJian Nasional (UN)}

Ujian Nasional sebagai instrument evaluasi terhadap prestasi belajar peserta didik mempunyai landasan kuat kuat guna implementasinya di sekolah. Beberapa regulasi yang digunakan dalam implementasi ujian nasional adalah;

Dasar Hukum Dan Pedoman Pelaksanaan

a. UU No. 20/2003 tentang Sisdiknas Pasal 58 Ayat (2) "Evaluasi peserta didik, satuan pendidikan, dan program pendidikan dilakukan oleh lembaga mandiri secara berkala, menyeluruh, transparan, dan sistemik untuk menilai pencapaian standar nasional pendidikan”

b. PP No. 19/2005 tentang Standar Nasional Pendidikan

c. Permen Diknas No. 77/2008 dan No. 78/2008 tentang UN SMP/ MTs/ SMPLB, SMA/ MA/SMALB, DAN SMK Tahun Pelajaran 2007/2009

Peserta UN dinyatakan lulus jika memenuhi standar kelulusan UN sebagai berikut:

a. Memiliki nilai rata-rata minimal 5.50 untuk seluruh mata pelajaran yang diujikan, dengan nilai minimal 4.00 untuk paling banyak dua mata pelajaran dan minimal 4.25 untuk mata pelajaran lainnya dan;

b. Khusus untuk SMK, nilai mata pelajaran Kompetensi Keahlian Kejuruan Minimum 7.00 dan digunakan untuk menghitung rata-rata UN.

Sedangkan pada tahun tahun 2014 ini standar kelulusan UN mengalami peningkatan yaitu;

a. Nilai setiap mata pelajaran yang di ujian nasionalkan minimal 4,0 
b. Rata-rata nilai akhir untuk semua mata pelajaran paling rendah adalah 5,5

Adapun tujuan UN adalah:

Menilai pencapaian kompetensi lulusan secara nasional pada mata pelajaran tertentu dalam kelompok mata pelajaran ilmu pengetahuan dan teknologi.

Kegunaan Hasil UN

a. Pemetaan mutu program dan/atau satuan pendidikan

b. Dasar seleksi masuk jenjang pendidikan berikutnya

c. Penentuan kelulusan peserta didik dari program dan/atau satuan pendidikan

d. Dasar pembinaan dan pemberian bantuan kepada satuan pendidikan dalam upaya meningkatkan mutu pendidikan.

\section{Menyikapi Ujian Nasional (UN) Selama Ini}

Perdebatan muncul tidak hanya karena kebijakan UN yang digulirkan Departemen Pendidikan Nasional minim sosialoisasi dan tertutup, tetapi lebih pada hal yang bersifat fundamental secara yuridis dan pedagogis. Dari hasil kajian Koalisi pendidikan, setidaknya ada empat penyimpangan dengan digulirkannya UN.

Pertama, aspek pedagogis. Dalam ilmu kependidikan, kemampuan

peserta didik mencakup tiga aspek, yakni pengetahuan (kognitif), keterampilan (psikomotorik), dan sikap (afektif). Tapi yang dinilai dalam UN hanya satu aspek kemampuan, yaitu kognitif, sedangkan kedua aspek lain tidak diujikan secara nasional sebagai penentu kelulusan.

Kedua, aspek yuridis. Beberapa pasal dalam UU Sisdiknas No. 20 Th. 2003 telah dilanggar, misalnaya pasal 35 ayat 1 yang menyatakan bahwa standar nasional pendidikan terdiri atas standar isi, proses, kompetensi lulusan, tenaga kependidikan, sarana dan prasarana, pengelolaan, pembiayaan, dan penilaian pendidikan, yang harus ditingkatkan secara berencana dan berkala. UN hanya mengukur kemampuan pengetahuan dan penentuan standar pendidikan yang ditentukan secara sepihak oleh pemerintah. Selain itu Pasal 58 ayat 1 menyatakan, evaluasi hasil hasil belajar peserta didik dilakukan oleh pendidik untuk memantau proses, kemajuan, dan perbaikan hasil belajar peserta didik secara berkesinambungan. Kenyataannya, selain merampas hak guru melakukan penilaian, UN mengabaikan unsur penilaian yang berupa proses. Selain itu, pada pasal 59 ayat 1 
dinyatakan, pemerintah dan pemerintah daerah melakukan evaluasi terhadap pengelola, satuan jalur, jenjang dan jenis pendidikan. Tetapi dalam UN pemerintah hanya melakukan evaluasi terhadap hasil belajar siswa yang sebenarnya merupakan tugas pendidik.

Ketiga, aspek sosial dan psikologis. Dalam mekanisme UN yang diselenggarakannya, pemerintah telah mematok standar nilai ratarata kelulusan mencapai 5.50 untuk seluruh mata pelajaran yang diUN-kan dengan tidak ada nilai di bawah 4.25 atau boleh ada nilai 4.00 untuk paling banyak dua mata pelajaran. ini menimbulkan kecemasan psikologis bagi peserta didik dan orang tua siswa. Siswa dipaksa menghafal pelajaran-pelajaran yang akan di-UN-kan di sekolah ataupun di rumah.

Keempat, aspek ekonomi. Secara ekonomis, pelaksanaan UN memboroskan biaya dan rawan terhadap adanya kecurangan dan korupsi. ${ }^{6}$

\section{Dampak Positif Dan Negatif Ujian Nasional (UN)}

Meskipun dari berbagai kalangan banyak yang tidak menyetujui UN, namun jika ditilik dari sisi lain UN pun bisa juga membawa dampak positif. Berikut ini akan dikemukakan dampak positif dan negatifnya.

\section{Dampak positif}

a. Seperti yang penulis amati, ketika mendekati UN kecemasan tidak hanya dimiliki oleh siswa namun orang tua pun sangat ikut merasakannya, sehingga banyak orang tua saat ini yang sangat memperhatikan anaknya dalam meningkatkan prerstasi belajarnya. Hal ini dapat dilihat dengan kerelaan orang tua (yang menengah ke bawah pun) untuk menitipkan anaknya pada lembaga-lembaga bimbingan belajar (bimbel) meskipun biayanya relatif mahal.

b. Siswa lebih serius dan semangat dalam belajarnya, sehingga dapat meminimalisir waktu senggang mereka oleh hal-hal yang kurang berguna.

c. Yang paling membawa dampak positif di sini adalah lembagalembaga bimbingan belajar (bimbel) itu sendiri, yang semakin banyak merauk keuntungan. Betapa tidak banyak lembaga

${ }^{6}$ Syamsir Alam, Evaluasi Tidak Harus Identik Dengan Ujian Nasional. Kompas/Senin, 26 April 2004, hal. 32 
tersebut tidak pernah sepi dikunjungi siswa mulai dari sekolah dasar sampai sekolah menengah ke atas. ${ }^{7}$

\section{Dampak Negatif}

Dalam hal ini, siswa menjadi lupa bahwa dirinya mempunyai bakat dan kemampuan tertentu, sehingga tidak dihiraukannya. Mereka juga lupa bahwa sekolah merupakan tempat pengembangan kepribadian bukan untuk mencari nilai semata. Lebih dari itu, tidak jarang orang tua dengan mudahnya menukarkan kasih sayang mereka dengan angka atau nilai 5.50 dalam ijazah. Jika anak-didiknya tidak lulus, mereka tidak segan-segan untuk mengatakan, "bodoh" dan semacamnya kepada anak mereka sendiri, meskipun mereka berbakat dalam bidang tertentu. Padahal, mereka telah matia-matian berusaha untuk mendapatkan selembar ijazah tersebut.

Dari sekian dampak negatif, beberapa hal berikut ini kiranya bisa mencerminkan keseluruhan dampak negatif yang ada.

a. Terjadinya bunuh diri. Hal ini disebabkan oleh citra buruk UN yang tidak meluluskan siwa yang kurang memenuhi standar. Sayangnya, mereka menyambut UN seolah-olah taruhan antara hidup dan mati. Sehigga, ketika mereka tidak lulus sekolah memilih bunuh diri. Penyebab lain adalah malu, citra bodoh, dan lemahnya iman. Hal ini disebabkan oleh - semenjak UN diberlakukan - pelajaran selain yang di-UN-kan dianggap tidak penting, termasuk plajaran agama. Padahal kita tahu bahwa pelajaran agama juga cukup penting untuk mengembangkan kepribadian siswa manusia seutuhnya. Lebih ironis lagi yaitu ketika madrasah pada umumnya yang nota bene dianggap lebih bisa menghasilkan output yang agamis malah ikut-ikutan juga hanya memfokuskan pada tiga mata pelajaran yang din UN kan, sehingga terkesan meremehkan pelajaran agama.

b. Memarjinalkan diri. Banyak siswa yang mempunyai bakat tertentu. Tetapi, gara-gara UN bakatnya tidak bisa berkembang dengan baik karena diforsir mengejar lulus.

c. Ketidak-adilan. Bagaimana dengan sekolah-sekolah di daerah pelosok, seperti di Papua, Bengkulu, Sulsel dan lain sebagainya?

${ }^{7}$ Neutron dan Primagama tahun 2006 saja sudah memasang tarif masing-masing 1.700. 000.- dan 2.500.000,-untuk biaya mengikuti les di lembaganya selama 2 semester, dengan tiga kali masuk dalam sepekan, @ 90 menit, apalagi pada 2014 tahun ini, tentunya akan lebih tinggi biaya yang dipungut. 
menurut informasi di berbagai media, di sekolah-sekolah di sana masih kekurangan guru, tidak ada perpustakaan, apalagi Labolatorium komputer dan Labolatorium bahasa. Bahkan, ketika musim tanam, mereka lebih berat untuk bercocok tanam membantu orang tuanya dari pada berangkat ke sekolah. Jangankan lembaga les atau guru privat seperti di kota-kota besar, orangtua mereka sendiri pun kurang perhatian terhadap sekolah anak-anaknya. Bagaimana mungkin meraka hendak distandarkan dengan sekolah-sekolah perkotaan? Sesungguhnya, film, "Laskar Pelangi" yang sedang menggegerkan dunia perfilman saat ini bisa menjadi kritik yang tajam kepada mereka yang sedang memegang kebijakan pendidikan. Sungguh tidak masuk akal, jika SMP N 5 yogyakarta hendak distandarkan dengan SMP N 5 Papua, misalnya. Siapa pun orangnya - yang masih menjunjung akal sehat dan hati nurani - tidak akan menstandarkan mereka dengan cara yang demikian.

d. Sam M. Chan dalam tulisannya menemukan bahwa Ujian nasional banyak terjadi kebocoran dan penyimpangan, campur tangan pemerintah masih banyak, orientasi sekolah hanya mengejar NEM, dan politisasi Ujuan Nasional sebagai usaha untuk mengangkat sekolah negeri agar terkesan berkualitas dengan menggunakan NEM sebagai seleksi masuknya. ${ }^{8}$

\section{E. tandarisasi Pendidikan: Mengapa Harus dengan UN?}

Menurut hemat penulis cara yang lebih elegan untuk menstandarisasi mutu pendidikan adalah dengan menstandarkan tenaga kependidikan dan sarana-prasarana serta fasilitas pendidikan. Sepertinya, gagasan ini akan mudah terwujud mengingat disahkannya UU guru dan dosen, di mana semua guru di lembaga pendidikan harus berijazah S1 atau D4. Sementara itu, agenda pemerintah untuk mensertifikasi guru layak disambut dengan antusias. Sebab, ditangan mereka lah pendidikan berada. Terlebih lagi jika kurikulum 2013 sekarang ini hendak dilaksanakan secara total. Tentu, jika UN tetap diberlakukan, maka kurukulum ini akan mendapat benturan keras. Pendapat lain menyatakan UN seharusnya hanya digunakan sebagai pengendali mutu pendidikan dan bukan untuk menentukan kelulusan.

Dengan demikikan, untuk melakukan stantadisasi mutu secara nasional, bukan menentukan hasilnya - nilai seluruh mata pelajaran wajib

8 Sam M. Chan, Analisis SWOT: Kebijakan Pendidikan Di Era Otonomi Daerah (Jakarta: PT: Raja Grafindo Persada, 2005), hal. 50 
minimal 5.50 misalnya. Tetapi, lebih akurat dengan menstandarkan proses belajar mengajar dengan segala sarana dan prasarana serta pembiayaan pendidikan. Misalnya, seluruh sekolah disama-ratakan dalam kepemilikan fasilitas belajar-mengajar, sepeti: semua gurunya minimal S1/ D4, perpustakakan dengan jumlah judul buku tertentu, Labolatorium komputer, Labolatorium bahasa, dan lain sebagainya. Dengan ini tanpa standarisasi nilai UN pun, semua anak didik akan lulus dengn hasil yang jauh membanggakan dari yang diharapkan: sekedar angka atau nilai.

Jika dihubungkan dengan kurikulum, maka UN juga tidak sejalan dengan salah satu prinsip yang dianut dalam pengembangan kurikulum yaitu diversifikasi kurikulum. Artinya bahwa pelaksanaan kurikulum disesuaikan dengan situasi dan kondisi daerah masing-masing. Kondisi sekolah di Jakarta dan kota-kota besar tidak bisa disamakan dengan kondisi sekolahsekolah di daerah perkampungan, apalagi di daerah terpencil. Kondisi yang jauh berbeda mengakibatkan proses belajar mengajar juga berbeda. Sekolah di lingkungan kota relatif lebih baik karena sarana dan prasana lebih lengkap. Tetapi di daerah-daerah pelosok keberadaan sarana dan prasarana serba terbatas, bahkan kadang jumlah guru pun kurang dan yang ada pun tidak kualified akibat ketiadaan.

Dilihat dari kebijakan otonomi daerah sebagaimana diatur dalam Undang-Undang No. 22 Tahun 1999 UN pun nampak bertentangan. Hal ini dapat dipahami sebagai berikut. Kebijakan UN dilaksanakan bersamaan dengan dikeluarkannya kebijakan otonomi daerah. Selain itu pada saat yang sama juga dikenalkan kebijakan otonomi sekolah melalui manajemen berbasis sekolah. Evaluasi sudah seharusnya menjadi hak dan tanggung jawab daerah termasuk sekolah, tetapi pelaksanaan UN telah membuat otonomi sekolah menjadi terkurangi karena sekolah harus tetap mengikuti kebijakan UN yang diatur dari pusat. Selain itu UN berfungsi untuk menentukan kelulusan siswa. Padahal pendidikan merupakan salah satu bidang yang diotonomikan, kecuali sistem dan perencanaan pendidikan yang diatur secara nasional termasuk kurikulum. Di sisi lain, dengan adanya kebijakan otonomi sekolah yang berhak meluluskan siswa adalah sekolah melalui kebijakan manajemen berbasis sekolah. UN telah dijadikan alat untuk "menghakimi" siswa."

\section{F. Solusi Alternatif Ujian Nasional (UN)}

Ada dua alternatif yang bisa ditawarkan. Pertama, UN tetap diberlakukan, tetapi dibagi dalam tiga model, yaitu UN model "A", "B",

\footnotetext{
${ }^{9}$ http://titored. Files. Wordpress. com
} 
dan "C". Untuk lembaga pendidikan yang terakreditasi "A", maka UNnya adalah UN model "A". Demikian pula untuk sekolah yang terakreditasi "B", maka UN-nya model "B". Demikian pula dengan sekolah terakreditasi " $C$ ". UN dengan model " $A$ ", "B", dan "C" ini bukan berarti membaut kelas-kelas yang memarjinalkan antara yang satu dengan yang lain. Sebab, model demikian hanyalah strategi untuk mewujudkan keadilan dalam konteks pendidikan.

Kedua, alternatif ke dua yaitu melaksanakan UN secara lokal (misalnya lingkup propinsi). Artinya pelaksanaan UN diserahkan pada tiap-tiap pemerintah daerah masing-masing yang lebih mengetahui standar mutu pendidikannya, sehingga soal ujian bisa lebih menyesuaikan dengan apa yang telah siswa dapat. ${ }^{10}$

Ketiga, apabila pemerintah tetap ingin melaksanakan UN secara merata, maka pemerintah wajib "sewajib-wajibnya" juga untuk memfasilitasi sarana dan prasarana sekolah-sekolah baik yang di perkotaan maupun di pedalaman secara merata. Jika semuanya telah merata, maka UN bisa dilakukan secara menyeluruh dan berkeadilan.

\section{G. PENUTUP}

Dari beberapa pemaparan di atas sungguh ironis apabila UN dijadikan standarisasi dalam penentuan kelulusan pendidikan, karena pendidikan merupakan satu kesatuan terpadu antara kognitif, afektif, dan psikomotor. Selain itu pendidikan juga bertujuan untuk membentuk manusia yang berakhlak mulia, berbudi luhur, mandiri, cerdas, dan kreatif yang semuanya itu tidak dapat dilihat hanya dengan penyelenggaraan UN. Dengan kata lain, UN belum memenuhi syarat untuk dipakai sebagai bentuk pertanggungjawaban penyelenggaraan pendidikan kepada masyarakat. Dalam arti didukung oleh bukti-bukti yang kuat dan memadai. Lebih dari itu siswa itu sendiri diharapkan dapat mempertanggung-jawabkan pencapaiannya lewat pengatahuan, sikap, tingkah laku dan skill yang dimilikinya dalam menghadapi hidup konkret beserta tantangannya di tengah masyarakat.

${ }^{10}$ Disampaikan oleh Bpk. Prof. Dr. Abdurrahman Assegaf, Dalam mata kuliah Politik Pendidikan Nasional. 


\section{DAFTAR PUSTAKA}

Anita Lie. Ujian Akhir Nasional, Kesenjangan Lulusan dan Tanggung jawab . Kompas: 10 mei 2004.

DEPDIKNAS, Undang-Undang Republik Indonesia No. 20 Tabun 2003 Tentang Sistem Pendidikan Nasional.

Nanang Fatah, Landasan Manajemen Pendidikan (Bandung: Remaja Rosdakarya, 1996), hal. 108

Sam M. Chan, Analisis SWOT: Kebijakan Pendidikan Di Era Otonomi Daerah. Jakarta: PT: Raja Grafindo Persada. 2005.

Syamsir Alam. Evaluasi Tidak Harus Identik Dengan Ujian Nasional. Kompas/Senin, 26 April 2004.

Zaenal Arifin. Evaluasi Instruksional. Bandung: Remajarosdakarya. 1991.

http://titored. Files. Wordpress. com 